\title{
A CLINICAL STUDY TO EVALUATE THE COMPARATIVE EFFICACY OF TEJAPATRA (CINNAMOMUM TAMALA) AND METHIKA BEEJA (TRIGONELLA FOENUM GRAECUM) CHURNA AND EXTRACTS IN THE MANAGEMENT OF MADHUMEHA \\ WITH SPECIAL REFERENCE TO TYPE-2 DIABETES MELLITUS
}

Vijay Chaudhary $^{1 *}$, Munish Sood ${ }^{2}$, B.L. Mehra ${ }^{1}$, Sameet Masand ${ }^{3}$

${ }^{1}$ Professor, P.G. Department of Kayachikitsa, R.G.G.P.G. Ayurveda College, Paprola, Himachal Pradesh, India ${ }^{2}$ Research Scholar, P.G. Department of Kayachikitsa, R.G.G.P.G. Ayurveda College, Paprola, Himachal Pradesh, India ${ }^{3}$ Assistant Professor, P.G. Department of Ras Shastra evum Bhaishajya Kalpana, V.Y.D.S. Ayurved Mahavidyalaya Khurja, Uttar Pradesh, India

Received on: 27/02/20 Accepted on: 16/04/20

\author{
*Corresponding author \\ E-mail: Drvijaychaudhary@gmail.com
}

DOI: 10.7897/2277-4343.110353

\begin{abstract}
Today the whole world is facing a pandemic of diabetes mellitus. Globally and nationally, diabetes mellitus with its complications has become one of the most important challenging health problems. Changing lifestyle and erroneous dietary habits are mainly responsible for its increasing incidence. A number of Ayurvedic herbal drugs are effective in the management of Madhumeha. Tejapatra (Cinnamomum tamala) and Methika Beeja (Trigonella foenum graecum) are also among them. But as the herbal anti diabetic drugs are required to be taken in bulk and invariably for life-long span hence some time their poor palatability becomes a big problem. In the present study, comparative efficacy of Churna and extract of Tejapatra and Methika Beeja has been clinically assessed on diabetes mellitus patients. Total 42 patients of Type- 2 diabetes mellitus were registered in the present clinical study and they were administered trial drugs for duration of 45 days. Patients were thoroughly assessed on various scientific parameters during complete trial period. Powder (Churna) and extract of Tejapatra and Methika Beeja were found significantly effective in the management of Type-2 diabetes mellitus but powder (Churna) showed definitely better effect over extract on various subjective, objective and biochemical parameters. No untoward effect was noticed during treatment and follow up period.
\end{abstract}

Keywords: Madhumeha, Type-2 Diabetes Mellitus, Tejapatra, Methika Beeja, Cinnamomum tamala, Trigonella foenum-graecum

\section{INTRODUCTION}

Madhumeha which is known to mankind since antiquity is a global health problem of clinical medicine as it is growing with full pace and alarming the world as a noninfectious pandemic. Incidence of diabetes mellitus is increasing day by day in our society. The reasons behind the increasing incidence of diabetes are basically multifactorial but the erroneous lifestyle is playing the central role. With the advent of automobiles and machines; the physical labour has been drastically reduced. Availability of calorie rich diet along with changing food habits, urban lifestyle and increased stress in the society has further deteriorated the scenario. Diabetes is fast gaining the status of a potential epidemic in India with more than 62 million diabetic individuals currently diagnosed with the disease. ${ }^{1,2}$ In 2000 , India (31.7 million) topped the world with the highest number of people with diabetes mellitus followed by China (20.8 million) with the United States (17.7 million) in second and third place respectively. According to Wild et al. ${ }^{3}$ The prevalence of diabetes is predicted to double globally from 171 million in 2000 to 366 million in 2030 with a maximum increase in India. It is predicted that by 2030 diabetes mellitus may afflict up to 79.4 million individuals in India, while China (42.3 million) and the United States (30.3 million) will also see significant increases in those affected by the disease. ${ }^{3,4}$

A number of anti-diabetic drugs right from insulin to hypoglycemic agents are available today but these drugs have their own limitations. None of the presently available antidiabetic drug possesses curative potential and more over these drugs are required to be taken for a lifelong span. Hence a lot of untoward effects are inevitable. Therefore, a need of safe and effective antidiabetic drug is always felt. A number of Ayurvedic drugs are effective in treating Madhumeha. Among them Tejapatra (Cinnamomum tamala) $)^{5}$ and Methika Beeja (Trigonella foenumgraecum $)^{6}$ also find their place. But these drugs are required to be taken in bulk and hence their poor palatability becomes a big problem. In the present study an effort has been made to assess the comparative efficacy of Churna and extract of Tejapatra and Methika Beeja in the management of Type-2 diabetes mellitus on various scientific parameters.

\section{MATERIAL AND METHODS}

\section{Selection of Patients}

A total of 42 patients of Type-2 Diabetes Mellitus were selected for the present study from O.P.D. and I.P.D. of Kayachikitsa Department, R.G.G.P.G. Ayurvedic College Hospital, Paprola and Himachal Pradesh, India irrespective of their sex and socioeconomic status, etc. IEC and Consent: - Approval from the Institutional Ethical Committee (IEC) was taken prior to begin with this study vide IEC 12/09. Written and informed consent of the patient was taken before their registration for the study. Patient fulfilling the inclusion criteria were randomly registered and divided into two groups. Study was carried out as per International conference of Harmonization-Good Clinical 
Practices Guidelines (ICH-GCP) or as per Declaration of Helsinki guidelines.

\section{Criteria for Diagnosis}

- Fasting blood glucose $\geq 126 \mathrm{mg} / \mathrm{dl}$

- Post Prandial blood glucose $\geq 200 \mathrm{mg} / \mathrm{dl}$

- $\mathrm{HbAlc} \geq 6.5$

\section{Inclusion Criteria}

- Patients willing to participate in the trial.

- Age between 35-80 years.

- Only uncomplicated cases of Type-2DM.

- Patients with FBS $\geq 126 \mathrm{mg} / \mathrm{dl}$.

\section{Exclusion Criteria}

- Patients unwilling to participate in the trial.

- Patients presenting with complications like severe renal disease, retinopathy, ischemic heart disease, severe hypertension etc.

- Type-1DM / Juvenile diabetes, pancreatic surgery.

- Patients with associated major medical diseases like cancer, concurrent infection like tuberculosis etc.

- Patient with FBS $>200 \mathrm{mg} / \mathrm{dl}$

\section{Laboratory Investigations}

Base line laboratory investigations were carried out in the registered patients to confirm the diagnosis and to rule out other concomitant disease both before and after the therapy.

- Blood- $\mathrm{Hb}$ gm\%, TLC, DLC, ESR, FBS, PPBS, HbA1c, Blood Urea, Serum Creatinine, Serum Cholesterol.

- Urine - Routine and Microscopic.

\section{Method of Study}

Trial Groups - Total 42 patients of Type-2 diabetes mellitus were selected for the present clinical study, they were randomly divided into two groups and treatment was given as follows.
Group - I: Total 22 patients were registered in trial group-I and out of them 2 patients discontinued the treatment and only 20 patients completed the study. The selected patients were given the trial drugs i.e. a combination of Tejapatra and Methika Beeja Churna in equal quantity in the dose of $15 \mathrm{~g}$, twice a day with plain water before food.

Group - II: Total 20 patients were registered in trial group - II and out of them 3 patients discontinued the treatment and only 17 patients completed the study. The selected patients were given a combination of hydro-alcoholic extract of Tejapatra and Methika Beeja in equal quantity in a dose of 1 gm twice a day and with plain water before food.

Duration of Trial: Duration of trial was 45 days.

Patients of both the groups were given similar advises regarding diet and exercise. All the patients were advised to take plenty of green leafy vegetables and to avoid high glycemic index food and fats. They were further advised to take light exercises daily and to avoid sternous physical exercise.

\section{RESULTS}

Registered patients were thoroughly assessed for any improvement in the subjective and objective criteria after every 15 days till the completion of trial period of 45 days. Hematological, biochemical and urine examination were done both before and after the therapy. Various signs and symptoms and urine sugar were accorded grades according to the severity (Table 1). The results of the study were graded into four categories highly improved, moderately improved, mildly improved and unimproved (Table 2).

\section{DISCUSSION}

In trial group-I, $24.27 \%$ reduction in fasting blood sugar was observed while $21.26 \%$ reduction was observed in group-II. Reduction in FBS was statistically highly significant $(\mathrm{p}<0.001)$ in both the groups. But the inter group difference between the therapies was statistically insignificant $(p>0.05)$ (Table 3). Urine sugar was reduced by $68 \%$ in group - I and $61 \%$ in group - II. Reduction in urine sugar in both the groups was also statistically highly significant (Table 4).

Table 1: Assessment Criteria

\begin{tabular}{|c|c|c|c|}
\hline Urine Sugar & Grade & Symptoms & Grade \\
\hline Nil & 0 & Absent & 0 \\
\hline Trace & 1 & Mild & 1 \\
\hline+ & 2 & Moderate & 2 \\
\hline++ & 3 & Severe & 3 \\
\hline+++ & 4 & & \\
\hline++++ & 5 & & \\
\hline
\end{tabular}

Table 2: Criteria for overall assessment of Results

\begin{tabular}{|c|c|c|}
\hline S. No. & \multicolumn{2}{|c|}{ Overall effects of the therapy } \\
\hline 1. & Highly Improved & $\begin{array}{c}\geq 75 \% \text { relief in symptoms and signs and/or } \\
\geq 25 \% \text { reduction in FBS }\end{array}$ \\
\hline 2. & Moderately Improved & $\begin{array}{c}50-74.9 \% \text { relief in symptoms and signs } \\
\text { and/or } 20-24 \% \text { reduction in FBS }\end{array}$ \\
\hline 3. & Mildly Improved & $\begin{array}{c}40-49.9 \% \text { relief in symptoms and signs } \\
\text { and/or } 15-19 \% \text { reduction in FBS }\end{array}$ \\
\hline 4. & Not Improved & $\begin{array}{c}<40 \% \text { relief in symptoms and signs and/or } \\
<15 \% \text { reduction in FBS }\end{array}$ \\
\hline
\end{tabular}


Vijay Chaudhary et al / Int. J. Res. Ayurveda Pharm. 11 (3), 2020

Table 3: Comparative effect of Churna and extract of Tejapatra and Methika Beeja on fasting blood sugar

\begin{tabular}{|c|c|c|c|c|c|c|c|c|c|c|}
\hline \multirow{3}{*}{ Variable } & \multicolumn{5}{|c|}{ Trial Group I } & & & \multicolumn{3}{|c|}{ Trial Group II } \\
\hline & \multicolumn{2}{|c|}{ Mean } & \multirow{2}{*}{$\%$ relief } & \multirow{2}{*}{ \pm SEM } & \multirow[t]{2}{*}{$\mathbf{P}$} & \multicolumn{2}{|c|}{ Mean } & \multirow{2}{*}{$\begin{array}{c}\% \\
\text { relief }\end{array}$} & \multirow{2}{*}{ \pm SEM } & \multirow{2}{*}{ p } \\
\hline & BT & AT & & & & BT & AT & & & \\
\hline $\begin{array}{c}\text { Fasting blood } \\
\text { sugar }\end{array}$ & 166 & 125.7 & 24.27 & 5.35 & $<0.001$ & 156.29 & 123.06 & 21.26 & 2.6 & $<0.001$ \\
\hline
\end{tabular}

Table 4: Comparative effect of Churna and extract of Tejapatra and Methika Beeja on urine sugar

\begin{tabular}{|c|c|c|c|c|c|c|c|c|c|c|}
\hline \multirow{3}{*}{ Variable } & \multicolumn{5}{|c|}{ Trial Group I } & \multicolumn{5}{|c|}{ Trial Group II } \\
\hline & \multicolumn{2}{|c|}{ Mean } & \multirow[t]{2}{*}{$\%$ relief } & \multirow[t]{2}{*}{ \pm SEM } & \multirow[t]{2}{*}{$\mathbf{P}$} & \multicolumn{2}{|c|}{ Mean } & \multirow{2}{*}{$\begin{array}{c}\% \\
\text { relief }\end{array}$} & \multirow[t]{2}{*}{ \pm SEM } & \multirow[t]{2}{*}{$\mathbf{P}$} \\
\hline & BT & AT & & & & BT & AT & & & \\
\hline $\begin{array}{c}\text { Fasting Urine } \\
\text { sugar }\end{array}$ & 2.82 & 0.90 & 68.08 & 0.16 & $<0.001$ & 2 & 0.78 & 61 & 0.15 & $<0.001$ \\
\hline
\end{tabular}

Table 5: Comparative effect of Churna and extract of Tejapatra and Methika Beeja on clinical features

\begin{tabular}{|c|c|c|c|c|c|c|c|c|c|c|c|}
\hline \multirow[t]{3}{*}{ S. No. } & \multirow[t]{3}{*}{ Signs/Symptoms } & \multicolumn{5}{|c|}{ Trial Group I } & \multicolumn{5}{|c|}{ Trial Group II } \\
\hline & & \multicolumn{2}{|c|}{ Mean } & \multirow{2}{*}{$\begin{array}{c}\% \\
\text { relief }\end{array}$} & \multirow{2}{*}{$\stackrel{ \pm}{\mathbf{S E M}}$} & \multirow[t]{2}{*}{$\mathbf{p}$} & \multicolumn{2}{|c|}{ Mean } & \multirow{2}{*}{$\begin{array}{c}\% \\
\text { relief }\end{array}$} & \multirow{2}{*}{ SEM } & \multirow[t]{2}{*}{$\mathbf{p}$} \\
\hline & & BT & AT & & & & BT & AT & & & \\
\hline 1. & $\begin{array}{l}\text { Prabhuta Mutrata } \\
\text { (polyuria) }\end{array}$ & 1.36 & 0.45 & 66.9 & 0.20 & $<0.001$ & 1.33 & 0.5 & 62.4 & 0.15 & $<0.01$ \\
\hline 2. & $\begin{array}{c}\text { Pipasa } \\
\text { (polydipsia) }\end{array}$ & 1.5 & 0.41 & 72.66 & 0.13 & $<0.001$ & 1.4 & 0.6 & 57.14 & 0.13 & $<0.001$ \\
\hline 3. & Kshudha (polyphagia) & 1.5 & 0.63 & 58 & 0.22 & $<0.01$ & 1.5 & 0.6 & 40 & 0.16 & $<0.01$ \\
\hline 4. & $\begin{array}{c}\text { Shaithilya } \\
\text { (fatigue) }\end{array}$ & 1.28 & 0.43 & 66.4 & 0.14 & $<0.001$ & 1.5 & 0.7 & 53.33 & 0.13 & $<0.001$ \\
\hline 5. & $\begin{array}{c}\text { Karpada Suptata } \\
\text { (Numbness) }\end{array}$ & 1 & 0.62 & 38 & 0.18 & $>0.05$ & 1.12 & 0.75 & 33.03 & 0.18 & $>0.05$ \\
\hline 6. & $\begin{array}{l}\text { Karpada Daha (burning } \\
\text { sensation in hands and } \\
\text { feet) }\end{array}$ & 1.63 & 0.87 & 46.62 & 0.16 & $<0.01$ & 1.33 & 0.83 & 37.59 & 0.22 & $>0.05$ \\
\hline 7. & $\begin{array}{l}\text { Pindiko Udveshtana } \\
\text { (calf tenderness) }\end{array}$ & 1 & 0.37 & 63 & 0.6 & $<0.01$ & 1.16 & 0.66 & 41 & 0.22 & $>0.05$ \\
\hline 8. & $\begin{array}{l}\text { Mukha Sosha (dryness } \\
\text { of mouth) }\end{array}$ & 1.4 & 0.4 & 71.42 & 0.14 & $<0.001$ & 1.5 & 0.58 & 61.33 & 0.19 & $<0.001$ \\
\hline 9. & $\begin{array}{c}\text { Sandhi Shoola (joint } \\
\text { pains) }\end{array}$ & 1.16 & 0.66 & 43.1 & 0.23 & $>0.05$ & 1.33 & 0.83 & 37.59 & 0.22 & $>0.05$ \\
\hline 10. & $\begin{array}{c}\text { Vulval } \\
\text { (pruritus/Balanitis) }\end{array}$ & 1 & 0.25 & 75 & 0.23 & $>0.05$ & 1.16 & 0.5 & 56.89 & 0.20 & $<0.05$ \\
\hline
\end{tabular}

Table 6: Overall effects of the therapy in group-I and group-II

\begin{tabular}{|c|c|c|c|}
\hline S. No. & Overall effect of the Therapy & Group-I & Group-II \\
\hline 1. & Highly Improved & $9(45 \%)$ & $5(29.41 \%)$ \\
\hline 2. & Moderately Improved & $6(30 \%)$ & $4(23.53 \%)$ \\
\hline 3. & Mildly Improved & $2(10 \%)$ & $4(23.53 \%)$ \\
\hline 4. & Un Improved & $3(15 \%)$ & $4(23.53 \%)$ \\
\hline
\end{tabular}

Table 7: Effects of Therapy on Hematological and Biochemical Profile

\begin{tabular}{|c|c|c|c|c|c|c|c|c|}
\hline \multirow{2}{*}{ Parameters } & \multicolumn{3}{|c|}{ Group I } & \multicolumn{4}{c|}{ Group II } \\
\cline { 2 - 9 } & \multicolumn{2}{|c|}{ Mean 'p' } & \pm & SEM value & \multicolumn{2}{c|}{ Mean 'p' } & \multicolumn{1}{c|}{ SEM value } \\
\hline Hb gm\% & 11.56 & 11.68 & 0.02 & $<0.001$ & 11.81 & 11.92 & 0.03 & $<0.001$ \\
\hline TLC/Cumm & 7632 & 7604 & 18.19 & $>0.1$ & 7618 & 7573 & 17.24 & $<0.005$ \\
\hline Polymorphs (\%) & 46.88 & 46.76 & 0.24 & $>0.1$ & 47.66 & 47.41 & 0.23 & $>0.1$ \\
\hline Lymphocytes (\%) & 24.22 & 23.88 & 0.21 & $>0.1$ & 24.24 & 23.97 & 0.20 & $>0.1$ \\
\hline Monocytes (\%) & 1.02 & 1.20 & 0.12 & $>0.1$ & 1.17 & 0.86 & 0.17 & $>0.1$ \\
\hline Eosinophils (\%) & 1.02 & 1.04 & 0.10 & $>0.1$ & 1.00 & 1.08 & 0.11 & $>0.1$ \\
\hline ESR & 6.76 & 5.38 & 0.19 & $<0.001$ & 7.17 & 5.55 & 0.17 & $<0.001$ \\
\hline S. Cholesterol (mg\%) & 188.03 & 179.66 & 0.35 & $<0.0001$ & 187.27 & 182.06 & 0.29 & $<0.01$ \\
\hline Blood Urea (mg\%) & 24.54 & 24.34 & 0.05 & $<0.001$ & 24.68 & 24.57 & 0.08 & $>0.1$ \\
\hline S. Creatinine (mg\%) & 0.81 & 0.81 & 0.01 & $>0.1$ & 0.77 & 0.75 & 0.01 & $<0.001$ \\
\hline
\end{tabular}

The effects of the therapy in group - I on most of the clinical features like polyuria, polydipsia, fatigue and dryness of mouth was statistically highly significant $(p<0.001)$. The features like polyphagia, burning sensation in hands and feet and calf tenderness were statistically significantly improved $(\mathrm{p}<0.01)$ whereas features like numbness, joint pains and vulval pruritus/balanites showed statistically insignificant improvement $(p>0.05)$. Effects of the therapy in group - II showed statistically highly significant improvement ( $\mathrm{p}<0.001$ ) only on polydipsia, fatigue and dryness of mouth and statistically significant $(\mathrm{p}<$ 0.01) improvement on polyuria polyphagia and vulval pruritus/balanitis.

A statistically insignificant $(\mathrm{p}>0.05)$ improvement was observed on features like numbness, burning sensation in hands and feet, calf tenderness and joints pain in group - II. (Table 5) 
Overall effects of the therapy showed that in group - I, nine (45\%) patients were markedly improved, six $(30 \%)$ patients were moderately improved, two (10\%) patients were mildly improved, and three $(15 \%)$ patients did not show any improvement. In group-II, five $(29.41 \%)$ patients were markedly improved, four $(23.53 \%)$ patients were moderately improved, four $(23.53 \%)$ patients were mildly improved, and four $(23.53 \%)$ patients did not show any improvement (Table 6).

Most of the routine haematological and biochemical investigations remained within normal limitsin both the groups before and after the therapy and only serum cholesterol was statistically significantly reduced in both the groups (Table 7).

Effects of the therapy on fasting blood sugar, urine sugar and symptomatology clearly show that though both Churna as well as extract of Tejapatra and Methika Beeja are significantly effective in the management of Type- 2 diabetes mellitus but Churna shows definitely better effect over extract on various subjective, objective and biochemical parameters.

It has been established that Tejpatra Churna used in crude form contains more fiber which helps by reducing glucose absorption from gut by inhibiting galactosidase and glucosidase ${ }^{7}$. This drug can also be assumed to be acting at the level of pancreatic $\beta$-cells and thus increasing the insulin release, this can be explained on the basis that Tejpatra contain many aromatic oils and is widely, used in spices, now it is proved that all the spices help in activating the secretion of various digestive enzymes and hormones which helps in proper digestion and metabolism so it appears that Tejpatra may also stimulate directly or indirectly the $\beta$-cells of pancreas for proper insulin secretion. Ethanolic (50\%) extract of Cinnamomum tamala leaves significantly lowered the plasma glucose levels in normoglycemic and streptozotocininduced hyperglycemic rats while given orally. The extract also showed anti-hypercholesterolemic and anti-hyperlipidemic activity in streptozotocin-induced diabetic rats ${ }^{5}$.

It is found all over India and the fenugreek seeds are usually used as one of the major constituents of Indian spices. 4hydroxyleucine, a novel amino acid from fenugreek seeds increased glucose stimulated insulin release by isolated islet cells in both rats and humans ${ }^{8}$. Fenugreek seeds contain the unique major free amino acid 4 - hydroxy isoleucine (4-OH-11e) which has been characterized as one of the active ingredients in fenugreek for blood glucose control, another mechanism mentioned about the trial drug is that, it may be acting against the formation of islet amyloid polypeptide (IAPP) ${ }^{9}$. It had been discovered that IAPP to be occurring in human insulinomas and in pancreatic islets with type- 2 diabetes mellitus, which have shown to inhibit insulin secretion. It has been further proved that fenugreek seeds lead to increase in erythrocyte insulin receptors and increased metabolic clearance rate. It is also found to improve peripheral glucose utilization and exert its hypoglycemic effect by acting at insulin receptor as well as at gastrointestinal level. Methi regulate metabolic pathways in glucose metabolism by enhancing liver activity and delay the absorption of glucose from the intestines, the whole powder of Trigonella foenum graecum seeds and its extracts showed significant hypoglycemic activity at different prandial states. Chemical analysis showed that the major constituent of the soluble dietary fiber is galactomannan; the mode of action of the dietary fiber is by decreasing the rate of gastric emptying and decreasing the absorption of glucose from the small intestine. Oral administration of an alcoholic extract of Trigonella foenum graecum seeds significantly reduced the blood sugar levels of normal as well as of alloxan-induced diabetic rats ${ }^{6}$.
Oral administration of 2 and $8 \mathrm{~g} / \mathrm{kg}$ of plant extract produced dose dependent decrease in the blood glucose levels in both normal as well as diabetic rats ${ }^{10}$. Administration of fenugreek seeds also improved glucose metabolism and normalized creatinine kinase activity in heart, skeletal muscle and liver of diabetic rats. It also reduced hepatic and renal glucose-6-phosphatase and fructose 1,6-biphosphatase activity ${ }^{11}$.

\section{CONCLUSION}

Effects of the therapy on fasting blood sugar, urine sugar and symptomatology clearly show that though both Churna as well as extract of Tejapatra and Methika Beeja are significantly effective in the management of Type-2 Diabetes Mellitus but Churna shows definitely better effect over extract on various subjective, objective and biochemical parameters. No untoward effect was noticed during treatment and follow up period in both groups.

However, this was only a pilot study and further multicentre double blind clinical studies are required with larger sample to establish high blood glucose controlling effect of these drugs.

\section{ACKNOWLEDGEMENT}

The authors are thankful to all the patients who willingly participated in this study. We are also thankful to the management of Rajiv Gandhi Govt. Post Graduate Ayurvedic College Hospital Paprola H.P., India and Govt. of Himachal Pradesh India for providing necessary assistance for completion of this research project.

\section{REFERENCES}

1. Joshi SR, Parikh RM India - diabetes capital of the world: now heading towards hypertension. J Assoc Physicians India 2007; 55: 323-4.

2. Kumar A, Goel MK, Jain RB, Khanna P, Chaudhary V. Australia as India towards diabetes control: Key issues Med J 2013; 6(10): 524-31.

3. Wild S, Roglic G, Green A, Sicree R, King H. Global prevalence of diabetes: estimates for the year 2000 and projections for 2030. Diabetes Care 2004; 27(5): 1047-53.

4. Whiting DR, Guariguata L, Weil C, Shaw IDF. Diabetes atlas: global estimates of the prevalence of diabetes for 2011 and 2030. J Diabetes Res Clin Pract 2011; 94(3): 311-21.

5. Sharma SR, SK Dwivedi, D Swarup; Hypoglycemic and hypolipidaemic effects of Cinnamomum tamala Nees leaves, Indian J Exp Biol 1996; 34(4): 372-74.

6. Vats V, SP Yadav, NR Biswas, JK Grover. Anti-cataract activity of Pterocarpus marsupium bark and Trigonella foenum-graecum seeds extract in alloxan diabetic rats, J Ethnopharmacol 2004; 93(2-3): 289-94.

7. Vijay Chaudhary, Sharad Johri, Ashwani Kumar Rana. Evaluation of Comparative Efficacy of Neelkanthi (Ajuga bracteosa), Tejapatra (Cinnamomum tamala) and Methika Beeja (Trigonella foenum graecum) Churna in the Management of Diabetes Mellitus. Int. J. Ayu. Pharma Research 2015; 3(2): 80-85.

8. Sauvaire Y, Petit P, Broca C, Manteghetti M, Baissac Y, Fernandez-Alvarez J, Gross R, Roye M, Leconte A, Gomis R, Ribes4-Hydroxyisoleucine: a novel amino acid potentiator of insulin secretion. G Diabetes 1998; 47(2): 206-10.

9. Manjiri Ranade and Nikhil Mudgalkar. A simple dietary addition of fenugreek seed leads to the reduction in blood glucose levels: A parallel group, randomized single-blind trial Ayu 2017; 38(1-2): 24-27. 
10. Khosla P, Gupta DD, Nagpal RK. Effect of Trigonella foenum graecum (Fenugreek) on blood glucose in normal and diabetic rats. Indian J Physiol Pharmacol 1995; 39(2): 173-4.

11. Gupta D, Raju J, Baquer NZ. Modulation of some gluconeogenic enzyme activities in diabetic rat liver and kidney: effect of anti-diabetic compounds. Indian J Exp Biol 1999; 37(2): 196-9.

\section{Cite this article as:}

Vijay Chaudhary et al. A Clinical Study to evaluate the Comparative efficacy of Tejapatra (Cinnamomum tamala) and Methika Beeja (Trigonella foenum graecum) Churna and Extracts in the management of Madhumeha with special reference to Type-2 Diabetes Mellitus. Int. J. Res. Ayurveda Pharm. 2020;11(3):20-24 http://dx.doi.org/10.7897/2277-4343.110353

Source of support: Nil, Conflict of interest: None Declared

Disclaimer: IJRAP is solely owned by Moksha Publishing House - A non-profit publishing house, dedicated to publishing quality research, while every effort has been taken to verify the accuracy of the content published in our Journal. IJRAP cannot accept any responsibility or liability for the site content and articles published. The views expressed in articles by our contributing authors are not necessarily those of IJRAP editor or editorial board members. 